\title{
MANAGERIAL DRIVERS OF CHINESE LABOUR LOYALTY IN INTERNATIONAL CONSTRUCTION PROJECTS
}

\author{
Weina ZHU ${ }^{\mathrm{a}}$, Ruochen $\mathrm{ZENG}^{\mathrm{b}}$, Xiaodong $\mathrm{LI}^{\mathrm{a}}$, Yi ZHU ${ }^{\mathrm{a}}$, c, Zhihui ZHANG ${ }^{\mathrm{a}}$ \\ ${ }^{a}$ Department of Construction Management, School of Civil Engineering, \\ Tsinghua Univ., Beijing 100084, China \\ ${ }^{b}$ M.E. Rinker, Sr. School of Construction Management, University of Florida, \\ Gainesville, FL, USA \\ ${ }^{c}$ HUARONG RONGDE ASSET MANAGEMNET CO., LTD, Beijing 100033, China
}

Received 10 Jun 2017; accepted 11 Sep 2017

\begin{abstract}
Organization performance is becoming ever more dependent on employee loyalty in the international construction projects. However, the improvement of construction labour loyalty on construction sites remains a largely neglected measure for reducing their turnover and improving their productivity. The purpose of this study was to quantitatively investigate the managerial drivers of labour loyalty, including macro-environment of the project host country, organizational living environment, job system, rewards, and communication, and to explore the significance of satisfaction as a mediating variable in the relationship between the managerial drivers and construction labour loyalty. First, hypotheses on the relationships between construction labour loyalty, satisfaction and the five managerial drivers were proposed. Second, structural equation modelling was adopted to test these hypotheses. Finally, the results demonstrated two types of influence paths: (1) macro-environment, job system and communication have significantly direct effects on construction labour loyalty, (2) mediated by satisfaction, organizational living environment and rewards offer positive indirect effects on construction labour loyalty. The first type of path serves as a long-term strategic orientation for improving labour loyalty. The second type of path is a tactic for short-term goals of labour loyalty enhancement. The research results can contribute to the body of knowledge of human resource management and the practice of enhancing labour productivity through improving construction labour loyalty in the context of international construction projects.
\end{abstract}

Keywords: international construction projects, construction labour, loyalty, managerial drivers, structural equation modelling.

\section{Introduction}

The economic performance of organization, whatever their sector of activity, is becoming ever more dependent on the participation, commitment, and more generally, loyalty of their employees (Guillon, Cezanne 2014; Boltanski, Chiapello 1999). International construction project organizations have higher levels of risk and complexity compared with domestic project (He 1995; Han et al. 2008). In the demanding conditions of international construction project, the construction employees will take more time to master the project-specific knowledge and skills as well as the adaptation to the international project conditions, including both living environment and working conditions (Jones et al. 2010). Therefore, the retention of qualified and experienced construction personnel can improve the productivity (Enshassi et al. 2007), decrease huge employee investment loss and hence improve organizational performance. Additionally, as the skill levels and experience of loyal workers increase, job-site safety and health concerns are likely to decline in the in- ternational construction sites (Kazaz et al. 2013). However, employee disloyalty, usually expressed in the way of labour turnover (Allen, Grisaffe 2001; Ineson, Berechet 2011), has often occurred in the international projects as a result of the industry's highly hazardous and stressful job conditions, low pay, national culture diversity, and the transient nature of construction workers (Chih et al. 2016; Liu et al. 2016; Steele, Sodhi 2006), resulting in potential risks to international project performance in many ways accordingly, including increasing cost to recruit, train and retain labour force, interrupting the workflow, and serious revenue loss when the required schedule is not met (Han et al. 2008; Hinze et al. 1985). These risks suggest that construction labour loyalty, generally both associated with employee productivity and turnover (Ling et al. 2012; Allen, Grisaffe 2001; Ineson, Berechet 2011), needs to receive much more attention as it pertains to international construction projects. 
Some literature on international construction projects reveals the relationships between construction labour loyalty and labour productivity. Ling et al. (2012) and Han et al. (2008) found that labour loyalty is positively associated with labour productivity. Consequently, some management guidelines and measures for enhancing workers' loyalty to the organization were recommended. Moreover, other research focused on the strategies for increasing employees' loyalty to the organization to reduce employee turnover in the construction industry. Chih et al. (2016) and Dainty et al. (2004) demonstrated employee turnover in the construction industry increases when organizations fail to meet individual expectations, leading to a breakdown in the employment relationship. Therefore, construction organizations should establish mechanisms for understanding and managing employees' psychological contracts and schemes for rewarding employees to strengthen employees' loyalty to the organization. Finally, in terms of the methodologies of studies, most studies explore directly the factors of loyalty while some research also demonstrated the mediation of satisfaction between the factors and loyalty. Othman (2014) quantified customer loyalty and satisfaction drivers by conducting an international survey questionnaire and meanwhile he identified satisfaction as a mediating variable in articulating employee loyalty.

The aforementioned studies lay a sound foundation for the study of construction labour loyalty. Those studies largely demonstrate that loyalty is undeniably effective in reducing employee turnover and increasing project performance. Nevertheless, those studies have several limitations, which require further investigation in a more cautious manner. The limitations include the following:

- Some studies have proposed that loyalty is a key antecedent of construction labour productivity. Nevertheless, few studies attempt to explore the antecedent factors of construction labour loyalty, which are far more decisive factors of construction loyalty and subsequently promote productivity.

- Some studies have begun to focus on employees' loyalty to reduce their turnover in the construction industry. Nevertheless, the subjects targeted by these studies are generally employees in domestic rather than international construction projects. In effect, the considerable turnover of construction labour in international projects is more likely to result in a high loss of productivity and contribute to a significant upsurge in on-site accidents; hence, the research results from domestic projects cannot be effectively applied to international project practice.

- From the perspective of owners, improved project performance is extremely significant. However, what is still needed is a quantitative examination of construction labour loyalty to substantially foster project performance.

To bridge these gaps, the main objective of this study was to quantitatively analyze the managerial drivers of labour loyalty in international construction projects and to explore the significance of satisfaction as a mediating variable in the relationship between the managerial drivers and construction labour loyalty by developing structural equation modelling (SEM). These managerial drivers primarily concern the living and working conditions that construction labourers were embedded. The relationships between labourers' loyalty and the managerial drivers can be strengthened by the inherent characteristic of international construction projects, for construction sites serve as both living places and workplaces during the period of project construction. These key influence factors and paths will provide contractors with decision points for encouraging and enhancing the non-project host country's labour loyalty to improve both labour productivity and organization performance in the international construction projects.

\section{Literature review}

\subsection{Employee loyalty and satisfaction}

The conception of employee loyalty is regarded as an extension of the notion of customer loyalty (Gronroos 1981). Supposing that employees are treated as "customers" of an organization, employee loyalty characterizes the relationship of an employee with the organization for which he or she works and has implications for the decision to remain with the organization (Allen, Grisaffe 2001; Turkyilmaz et al. 2011). Additionally, Becker et al. (1995) and Martensen and Grønholdt (2006) defined loyalty as a strong desire to remain the member of an organization, a willingness to make high levels of effort for the sake of the organization, and a strong emotional connection to the organization. They also argued that a loyal employee can endure some form of temporary dissatisfaction with the job. Therefore, the construction labour loyalty reported herein refers to a strong desire to remain in international construction projects, a willingness to endure temporary dissatisfaction with the project construction work, and a willingness to make high levels of efforts for the improvement of project performance.

The majority of employee loyalty research papers was restricted to the service industry, such as hotel, public sectors and banking (Ineson, Berechet 2011; Narteh, Odoom 2015; Turkyilmaz et al. 2011). Both the objectives and the methodologies of studies on the service industry are highly similar. Specifically, the objectives of these studies are to identify the key factors determining employees' loyalty within the organizational context in which they are embedded and, as a result, to help establish an effective and efficient management system. Methodologically, structural equation modelling was usually employed to test the theoretical hypotheses linking the employee loyalty and the constructs. Following the management models and techniques developed by the service industry, many researchers in the academic field of construction begin to show a growing interest in employee loyalty. 
Unlike employee loyalty, which is a more actionoriented concept because it addresses the behaviour of employees (Duboff, Heaton 2013), employee satisfaction is defined as a pleasurable or positive emotional state resulting from the appraisal of one's job or job experience. It is the gratification or sense of prosperity that employees obtain from their jobs (Eskildsen, Nussler 2000). Job satisfaction represents an effective response to the specific features of the job and an attitude toward the job, whereas employee loyalty is an effective response to the entire organization (Chen 2006). Based on the contrast presented above, job satisfaction reported in this study refers to construction labourers' expected, ideal and overall levels of satisfaction with their jobs in international construction (Smith 1969).

\subsection{The managerial drivers of employee loyalty and satisfaction}

An international construction project is one-off, mobile, and subject to environmental influences, and therefore construction labourers generally do not occupy a relatively fixed workplace. Rather, they are exposed to poor construction sites serving a dual role as both the living environment and the workplace during the long period of project construction. According to such characteristics above and the extensive literature on loyalty and satisfaction, three major types of drivers of employee loyalty and satisfaction have emerged from various existing studies, including working conditions, living conditions and demographic factors.

Living conditions are the environment that labourers were exposed to live on the international projects, which is a direct measurement of the quality of life in an international project (Austin, Droussiotis 2007). It includes the macro-environment in the project-host country (Wang 2006; Han et al. 2008), and the organizational living environment (Atiyyah 1995; Han et al. 2008). Working conditions range from the terms under which workers enter the employment relationship to the environment in which they perform their tasks (Carre 2015), which shape the 'way of doing work' (Piore 1990). It can mainly include the rewards (Linz et al. 2015; Tsigilis et al. 2006), job system (Chi et al. 2013; Fini et al. 2016; Kumar, Shekhar 2013), and communication (Smith, Rupp 2002; Turkyilmaz et al. 2011). Moreover, some studies have been conducted to better understand the relationship between demographic factors (age and gender) and loyalty (Helgesen et al. 2010). The related results indicated that age appears to have a positive effect on loyalty and the female is supposed to be more loyal than the male (Pan, Zinkhan 2006).

\section{Hypotheses}

Two types of relationships between five managerial drivers and construction labour loyalty were proposed: direct effects and indirect effects. The former considered construction labour loyalty as being directly affected by the five managerial drivers, whereas the latter viewed the five managerial drivers as primarily influencing job satisfaction, with job satisfaction in turn influencing construction labour loyalty.

\subsection{Loyalty and its managerial drivers}

Butcher et al. (2001) considered that one's feeling of anxiety or relaxation arising from the external social interaction has influence on his/her loyalty. From the perspective of long term, unfavorable macro-environment in the project host country will gradually make the labourers generate an intention to turnover and dissatisfaction of job. Therefore, the following hypothesis is formulated.

Hypothesis 1 (H1). Macro-environment has a positive effect on construction labour loyalty.

Due to the one-off characteristic of construction projects, few contractors invest huge sums of money into onsite living environments for construction labourers, especially for international construction projects, with their greater uncertainty and limitations. However, if contractors paid more attention to and professionally managed the aspects of construction sites such as food, accommodations and living facilities, and leisure time, labourers would likely become aware of the human-oriented management. Such awareness has positive effects on labour loyalty.

Hypothesis 2 (H2). Organizational living environment has a positive effect on construction labour loyalty.

Linz et al. (2015) found that worker loyalty is positively linked to a number of expected rewards. More specifically, a positive link between loyalty and earnings in socialist economies was revealed by Linz and Chu (2014). Therefore, the following hypothesis is formulated.

Hypothesis 3 (H3). Rewards has a positive effect on construction labour loyalty.

Kumar and Shekhar (2012) demonstrated that the job system significantly influences employee loyalty. In international construction projects, an impartial workload assignment system, necessary safety and training systems and a transparent incentive system strengthen labourers' trust in contractors and boost their moral, and as a result, fostering greater dedication to their jobs and organizations. Therefore, the following hypothesis is formulated.

Hypothesis 4 (H4). Job system has a positive effect on construction labour loyalty.

Through communication, management can keep employees informed about the procedures and processes, and also provide employees with a window to participate in all company activities, which will make them loyal (Narteh, Odoom 2015). Likewise, Smith and Rupp (2002) believed that communication is essential for developing employee loyalty. Therefore, the following hypothesis is formulated.

Hypothesis 5 (H5). Communication has a positive effect on construction labour loyalty. 


\subsection{Managerial drivers, satisfaction and loyalty}

These managerial drivers primarily concerned the living and working conditions have effects on both construction labour satisfaction and loyalty; meanwhile satisfaction is an antecedent to loyalty (Chen 2006). In other words, these managerial drivers have effects on labour loyalty through satisfaction. From the perspective of the effects from the managerial drivers, satisfaction is regarded as an endogenous variable, but in terms of the effect on labour loyalty, satisfaction also serves as an exogenous variable. According to the identification of mediator variable (Kline 2005), satisfaction, therefore, was regarded as the mediator in the entire model. Eskildsen and Nussler (2000), Matzler and Renzl (2007), Turkyilmaz et al. (2011) reported a significant mediating role of employee satisfaction on employee loyalty. As such, the following hypotheses are put forth.

Macro-environment in the project-host country, both natural and men-made environment, can have impacts on labourer adoption into the project-host country (Wang 2006) and thus have effects on their job satisfaction. Therefore, the following hypothesis is formulated.

Hypothesis 6 (H6). Macro-environment in the project-host country has a positive effect on construction labour job satisfaction.

The organizational living environment influences construction labour satisfaction because labourers want a living environment that provides greater physical comfort and reliable lifestyle support and hence promotes work productivity (Turkyilmaz et al. 2011). Some studies have shown that low job satisfaction levels can mainly be attributed to poor life environment (Marin-García et al. 2011). Therefore, the following hypothesis is formulated.

Hypothesis 7 (H7). Organizational living environment has a positive effect on construction labour job satisfaction.

Anne and Grønholdt (2007) suggested that rewards (e.g., pay and promotion) should be linked to organizational success as a result of employee satisfaction. Furthermore, rewards are even considered to be one of the key factors influencing employee satisfaction (Jun et al. 2006). Therefore, the following hypothesis is formulated.

Hypothesis 8 (H8). Rewards have a positive effect on construction labour job satisfaction.

Kazemzadeh and Bashiri (2005) investigated various studies related to employee satisfaction and found that job systems and processes are factors influencing employee satisfaction. Therefore, the following hypothesis is formulated.

Hypothesis 9 (H9). Job system has a positive effect on construction labour job satisfaction.

Communication influences employees' attitudes and behaviours toward a job (Mcclenahen 2003). Management can influence employees better through forms of communication that appeal to their positive emotions and encourage their involvement in their current job (Smith, Rupp 2002). Therefore, the following hypothesis is formulated.
Hypothesis 10 (H10). Communication has a positive effect on construction labour job satisfaction.

Chen (2006) asserted that job satisfaction is an antecedent to the organizational loyalty of employees, meaning that the organizational loyalty of employees develops from job satisfaction. With regard to construction projects, Shan and Goodrum (2010) believed that worker satisfaction plays an important role in retaining workers in the construction industry. Therefore, the following hypothesis is formulated.

Hypothesis 11 (H11). Job satisfaction has a positive effect on construction labour loyalty.

The construction labour loyalty theoretical framework is shown in Figure 1. The direct effects were explained by the five arrows representing the five hypotheses $\mathrm{H} 1, \mathrm{H} 2, \mathrm{H} 3, \mathrm{H} 4$ and $\mathrm{H} 5$. The indirect effects are mediated by job satisfaction, with six hypotheses H6, H7, H8, H9, H10 and H11.

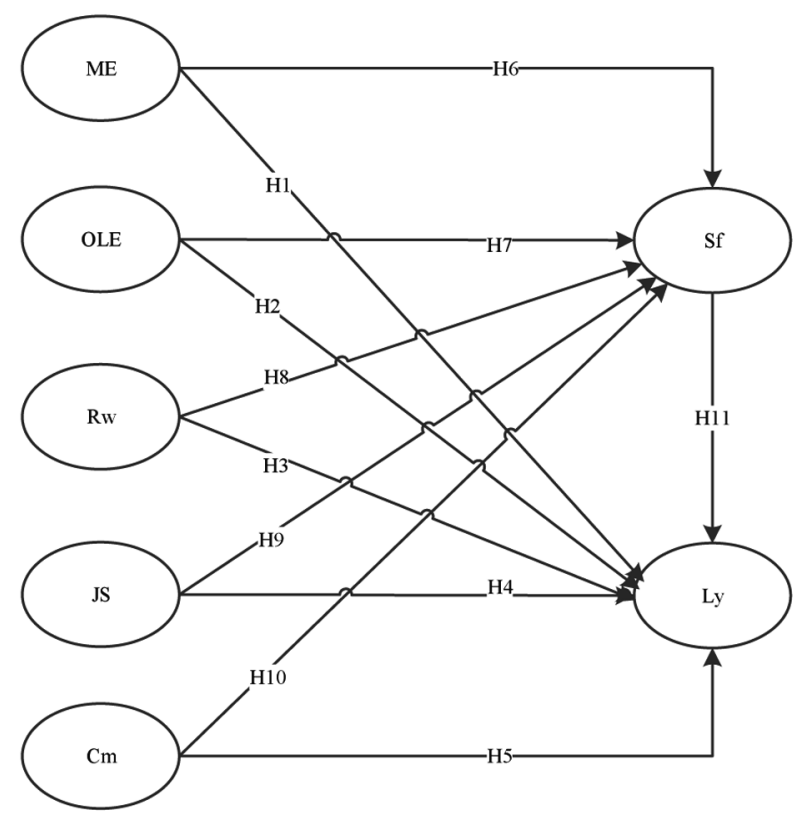

Fig. 1. Initial theoretical framework

\section{Methodology}

\subsection{Questionnaire survey}

\subsubsection{Measures}

A thorough literature review and expert interviews were conducted to identify the observable items of the constructs. First, the items for construction labour satisfaction are derived from the Minnesota Satisfaction Questionnaire (MSQ) of Smith (1969). Meanwhile, Ryan et al. (1995) also asserted that the measurement of satisfaction concept should be based on three aspects: a summary judgement of the satisfaction level, a comparison with expectations, and a comparison with an ideal situation. Thus, job satisfaction reported in this study was measured using three items (overall satisfaction, expected satisfaction and ideal satisfaction). 
In addition, because the existing employee loyalty scale has different items according to different industries, this study drew upon some of the items proposed by scholars who study customer loyalty (Mcmullan, Gilmore 2003; Zeithaml, Parasuraman 1996), and according to the characteristics of labour in the construction industry, three items for the measurement of worker loyalty (labourer's retention for the organization, labourer's endurance of dissatisfaction, labourer's devotion to construction work) were designed. The statistical results show that the scale has good reliability and validity.

Due to the absence of applicable scales in the literature of the managerial drivers in both living and working conditions, literature review and expert interviews were used to develop and adjust a scale to the specific context of the international construction project. According to Clark and Watson (1995), a clear conceptualization of the target construct is needed for objective scale development. The proper management of the rights and protections of labourers can foster the construction labour's loyalty to an organization (Narteh, Odoom 2015; Smith, Rupp 2002). In this study, numerous references on employee loyalty and satisfaction were visited and then 8 items of living conditions and 13 items of working conditions that focused on the enforcement of labourers' rights and protections were determined as described in Table 1.

To determine a more appropriate item list to explore the paths, eight experienced practitioners from CSCEC (China State Construction Engineering Corporation) were invited to give their opinions on the item list with respect to the context in their international projects. All the eight experts are managers who specialized in international project management, including risk management, labour management and contract management, and their seniority is ranging from 10 years to 30 years. Considerable attentions were paid in expert screening by rewording of items as well as items additions and deletions.

Finally, 27 items (3 items for loyalty, 3 items for satisfaction, 8 items for the living conditions, 13 items for the working conditions) were developed in this study presented in Table 1. A five-point Likert Scale was applied in this study, with "1" meaning very bad (or weak), "3" meaning medium and " 5 " meaning very good (or strong). The respondents need to issue their opinions based on their experience in the international projects. Moreover, some demographic information was also asked, including labourers' age, education and designation. Although many studies explored the effects of gender on loyalty, all the respondents reported in this paper were male. So the gender is not regarded as one of control variables to explore the effects on labourer' loyalty in the model.

\subsubsection{Data collection}

All the respondents to the questionnaire are the labourers participated in the international projects of CSCEC. The locations of international projects limited the labours filling in the questionnaires. To this end, the Overseas
Business Department of the CSCEC helped the process of questionnaire survey. All questionnaires were finished during the process that the CSCEC dispatched the labourers back home country for the formalities in batches. Through explaining and giving some examples about the questions in the questionnaire, the labourers filled out the questions on the scene by assessing their experience in the international projects. 1000 questionnaires were distributed to the labourers, of which 571 were returned and 399 were valid for further analysis. The valid response rate was $39.9 \%$.

\subsection{Data analysis}

Prior to the structural equation modelling, the original data is screened for possible problems (Kline 2005). First, missing value is ruled out in the data set. Second, the normality assumption of the distribution of each indicator is tested in terms of skewness index (SI) and kurtosis index (KI). The SI reported in this study ranges between -0.842 and 0.356 , whose absolute value is less than the recommended level of 3 (Kline 2005). The range for KI is between -1.261 and 1.023, the absolute value of which is less than 10 (Kline 2005). Therefore, the normality assumption for these indicators is not rejected.

Bivariate correlation is also used to detect the correlation between loyalty and the demographic variables. The age sample consists of five ranges: 20 below $(0.5 \%)$, 20-30 (22.3\%), 30-40 (43.3\%), 40-50 (32.1\%), and 50 above $(1.8 \%)$. Likewise, the education sample is separated into five ranges, primary school (3.0\%), junior high school (66.7\%), technical secondary school (10.8\%), senior middle school (14.7\%), college and above $40-50(4.8 \%)$. As for the designation, the majority of respondents $(91.0 \%)$ are ordinary workers; the rest $(9.0 \%)$ is the foreman. The results of bivariate correlation demonstrated that the correlation coefficient (Pearson) between the age and the loyalty is $0.184(\mathrm{p}<0.01)$ while neither the education nor the designation doesn't show significant correlation coefficient. Therefore, the age is used as a control variable in the follow-up structural model.

Exploratory factor analysis (EFA) was used to explore the latent variables underlying the drivers. In this study, principal components analysis (Varimax rotation) was done. The results showed that two factors of living conditions are identified (macro-environment in the project host country, and the organizational living environment), which explains $56.00 \%$ of the total variance. For working conditions, the first three factors (rewards, job system and communication) were determined; yet the fourth factor, together with its only one observable item (connection with family members), was deleted because Ringle et al. (2012) pointed out using only one manifest variable to represent one latent variable is a risky choice as it performs worse than multi-item scales in most situations. In addition, since the factor loading should be greater than the level of 0.50 (Ozorhon et al. 2007), two items (recognition and work training system) with 0.5 
Table 1. Summary of items

\begin{tabular}{|c|c|c|c|}
\hline Variables & Code & Items & Reference \\
\hline \multirow[t]{8}{*}{ Living conditions } & L1 & Climate of host-project country & Wang (2006) \\
\hline & $\mathrm{L} 2$ & Economy of host-project country & Wang (2006) \\
\hline & L3 & Public security of host-project country & Interview with professionals \\
\hline & L4 & Medical service of host-project country & Han et al. (2008) \\
\hline & L5 & Food in international construction sites & Interview with professionals \\
\hline & L6 & Accommodation and housing facilities & Atiyyah (1995) \\
\hline & L7 & Leisure time in the organization & Han et al. (2008) \\
\hline & L8 & Life constraints in the organization & Interview with professionals \\
\hline \multirow[t]{13}{*}{ Working conditions } & W1 & Salary level & Linz et al. (2015); Tsigilis et al. (2006) \\
\hline & W2 & Wage settlement & Zhou (2010) \\
\hline & W3 & Welfare & $\begin{array}{l}\text { Linz et al. (2015a, } 2015 \text { b); Kazemzadeh and } \\
\text { Bashiri (2005) }\end{array}$ \\
\hline & W4 & Promotion & Tsigilis et al. (2006) \\
\hline & W5 & Recognition & Tsigilis et al. (2006) \\
\hline & W6 & Work incentive system & Kumar and Shekhar (2013); Han et al. (2008) \\
\hline & W7 & Workload assignment system & Fini et al. (2016); Chi et al. (2013) \\
\hline & W8 & Work safety system on construction sites & Abrey and Smallwood (2014) \\
\hline & W9 & Work training system & Turkyilmaz et al. (2011) \\
\hline & W10 & Mutual communication among colleagues & Turkyilmaz et al. (2011); Smith and Rupp (2002) \\
\hline & W11 & Emotional management & Turkyilmaz et al. (2011); Han et al. (2008) \\
\hline & W12 & Communication forms & Turkyilmaz et al. (2011) \\
\hline & W13 & Connection with family members & Interview with professionals \\
\hline \multirow[t]{3}{*}{ Satisfaction } & Sf1 & Ideal satisfaction & \multirow{3}{*}{$\begin{array}{l}\text { Smith (1969); Ryan et al. (1995); } \\
\text { Helgesen et al. (2010) }\end{array}$} \\
\hline & Sf2 & Expected satisfaction & \\
\hline & Sf3 & Overall satisfaction & \\
\hline \multirow[t]{3}{*}{ Loyalty } & Ly1 & Retention & \multirow{3}{*}{$\begin{array}{l}\text { Allen and Grisaffe (2001); Martensen and } \\
\text { Grønholdt (2006); } \\
\text { Zeithaml and Parasuraman (1996); Mcmullan and } \\
\text { Gilmore (2003) }\end{array}$} \\
\hline & Ly2 & Endurance of dissatisfaction & \\
\hline & Ly3 & Devotion to construction work & \\
\hline \multirow[t]{3}{*}{ Demographic } & D1 & Age & Helgesen et al. (2010) \\
\hline & D2 & Education & Helgesen et al. (2010) \\
\hline & D3 & Designation & Interview with DB professionals \\
\hline
\end{tabular}

low loadings were deleted. So, the cumulative variance contribution rate of working conditions was $56.224 \%$. The factorial structure and its related statistics are listed in Table 2.

Four indicators are extracted as significant in the macro-environment in the project host country. These indicators describe the characteristic of external environment of international construction projects. Four indicators are extracted as significant in the living environment. These indicators refer to the life necessities provided and created by contractors for construction labourers in international construction project. Four indicators are extracted as significant in the rewards. They are the direct returns that construction labourers are given by virtue of the fruits of their labour. Three indicators are extracted as significant in job system. It refers to the context surrounding the labourers' work, which aims to build up labourers' identification with and trust in the managers. Three indicators are extracted as significant in communication which describe the communication context of labourers in the international projects. Accordingly, the managerial drivers reported herein embrace the five dimensions: macro-environment in project-host country, organizational living environment, rewards, job system, and communication.

\section{Results}

The model was analyzed with Amos 21.0 software. Confirmatory factor analysis (CFA) provided the first step to demonstrate satisfactory measurement of the constructs. Then structural equation modelling was used to analyze the causal effects of the structural model. 
Table 2. Factor analysis results of the drivers of loyalty

\begin{tabular}{|c|c|c|c|c|c|}
\hline & Factors & No. & Items & Loadings & $\begin{array}{l}\text { Cumulative } \\
\text { variance }\end{array}$ \\
\hline \multirow{8}{*}{$\begin{array}{l}\text { Living } \\
\text { conditions }\end{array}$} & \multirow[t]{4}{*}{ Macro environment (ME) } & ME1 & Climate & .583 & \multirow[t]{8}{*}{56.00} \\
\hline & & ME2 & Economy & .810 & \\
\hline & & ME3 & Security & .804 & \\
\hline & & ME4 & Medical service & .508 & \\
\hline & \multirow{4}{*}{$\begin{array}{l}\text { Organizational living environment } \\
\text { (OLE) }\end{array}$} & OL1 & Food & .728 & \\
\hline & & OL2 & Accommodations & .728 & \\
\hline & & OL3 & Leisure time & .579 & \\
\hline & & OL4 & Life constraints & .679 & \\
\hline \multirow{10}{*}{$\begin{array}{l}\text { Working } \\
\text { conditions }\end{array}$} & \multirow[t]{4}{*}{ Rewards (Rw) } & Rw1 & Salary level & .723 & \multirow[t]{10}{*}{$56.224 \%$} \\
\hline & & Rw2 & Wage settlement & .724 & \\
\hline & & Rw3 & Benefit package & .608 & \\
\hline & & Rw4 & Promotion & .660 & \\
\hline & \multirow[t]{3}{*}{ Job system (JS) } & JS1 & Work incentive system & .805 & \\
\hline & & JS2 & Workload assignment system & .802 & \\
\hline & & JS3 & Work safety system & .568 & \\
\hline & \multirow[t]{3}{*}{ Communication $(\mathrm{Cm})$} & $\mathrm{Cm} 1$ & $\begin{array}{l}\text { Mutual communication among } \\
\text { colleagues }\end{array}$ & .775 & \\
\hline & & $\mathrm{Cm} 2$ & Emotional management & .771 & \\
\hline & & $\mathrm{Cm} 3$ & Communication forms & .771 & \\
\hline
\end{tabular}

\subsection{Measurement models}

Cronbach's alpha is used to test the reliability of the hypothesized construct based on the data. Values ranging from 0.6 to 0.7 are regarded as sufficient, and values higher than 0.7 are regarded as good in reliability testing (Doloi et al. 2012). According to the Cronbach's alpha if item deleted in SPSS, the Cronbach's alpha value of loyalty was 0.640 if deleted item Ly3. But the Cronbach's alpha of loyalty with three items initially is 0.503 so Ly3 was deleted. Finally, as shown in Table 3, all Cronbach's alphas of the constructs reported in this paper were sufficiently reliable.

In the measurement model of CFA as shown in Figure 2, the standardized factor loadings less than 0.5 are considered for deletion (Xiong et al. 2015), and thus five items (OLE4, Rw4, ME1, Cm1, Sf3) were deleted because they are low 0.5 or very close to 0.5 . As shown in Table 3, the result demonstrated that factor loadings ranged from 0.550 to 0.936 . Moreover, as shown in Table 3 , the composite reliability (CR) satisfies the criteria that Kline (2005) pointed out that 0.5 above is the minimum acceptable range; average variance extracted (AVE) also satisfies the criteria that the value should be above 0.50 (Fornell, Larcker 1981) except the rewards and job system with slight smaller than 0.5 . However, the results cannot be rejected because the intrinsic fit of measurement model may provide evidence of the validity (Anderson, Gerbing 1988).

Based on recommendation from previous literatures, a model reflects a good fit by attaining: (1) the absolute normed $\chi^{2} /$ degree of freedom $<5.00$ (Ye et al. 2015); (2) goodness-of-fit index (GFI) $>0.85$ (Maruish 2004); (3) root mean square error of approximation (RMSEA) $<0.1$ (Chou, Bentler 1990); (4) the incremental measure of comparative fit index (CFI) $>0.90$ (Hair et al. 2014); as well as (5) parsimony fit measure of adjusted goodness-of-fit index (AGFI) $>0.8$ (Maruish 2004). The measurement model with 18 indicators and seven constructs (Fig. 2) resulted in a good overall model fit $\left(\chi^{2} /\right.$ degree of freedom $=2.87$, RMSEA $=0.069, \mathrm{GFI}=0.915$, $\mathrm{CFI}=0.907, \mathrm{AGFI}=0.873, \mathrm{IFI}=0.908, \mathrm{NFI}=0.866$, TLI $=0.875$ ). Hence, these measures for the model lent sufficient support for the results to be deemed an acceptable representation of the hypothesized constructs.

The research instrument adopts a self-reporting survey measurement method. Therefore, the findings may have the potential risk of common method variance. Therefore, data were also tested for common method bias using Harman's single-factor test (Podsakoff, Organ 1986). The resulting one-factor measurement model $\left(\chi^{2} /\right.$ degree of freedom $=5.443$, RMSEA $=0.106, \mathrm{GFI}=$ 0.816 , AGFI $=0.768$, CFI $=0.736$ ) had much worse fit indices than the proposed measurement model. Therefore, common method bias was not evident.

\subsection{Structural model}

The structural model shows potential causal dependencies between the seven latent variables and the direct effects connecting them. A similar set of overall fit statistics for the measurement model is used to examine the 


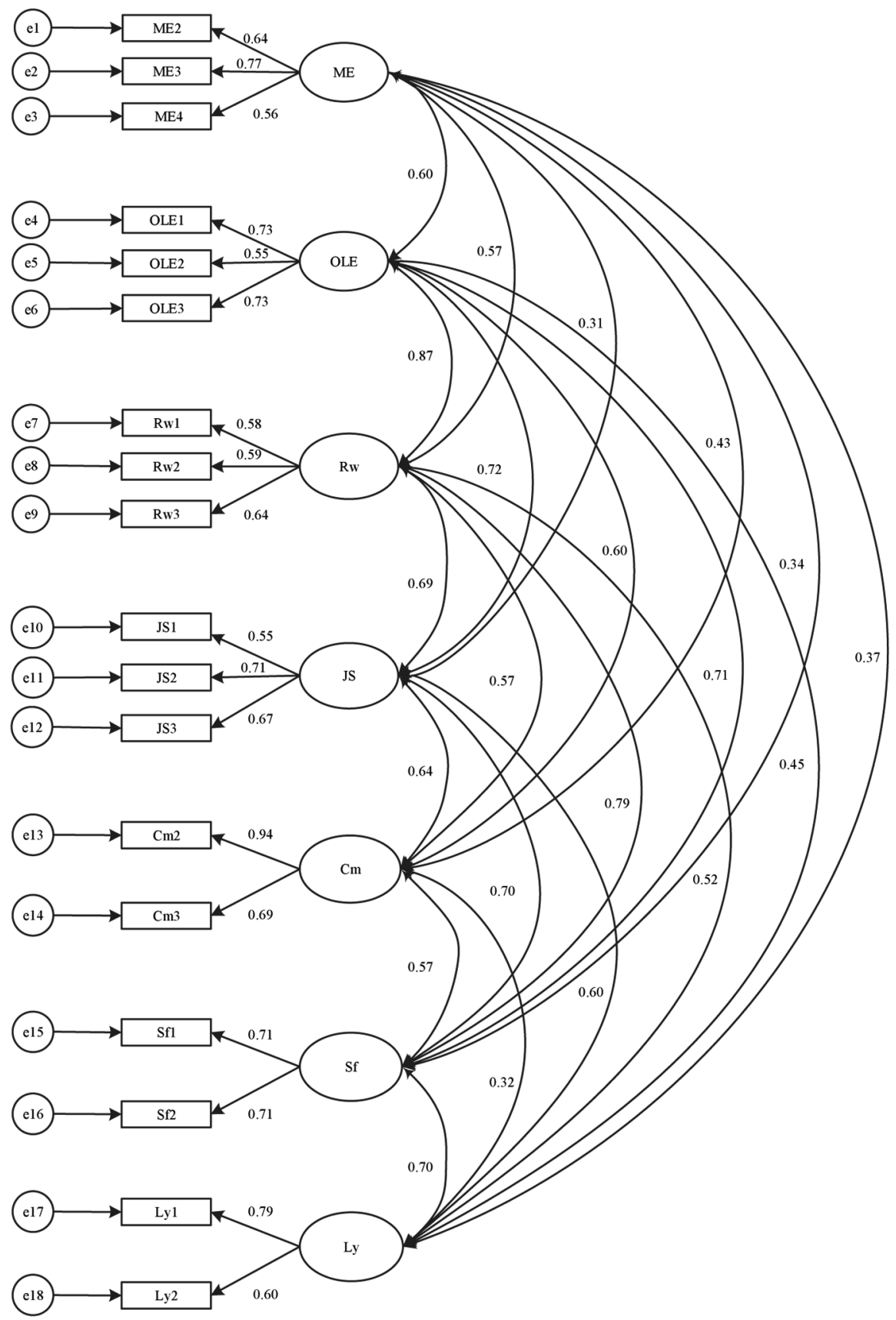

Fig. 2. Measurement model

structure equation model. The structural model resulted in an acceptable overall model fit $\left(\chi^{2} /\right.$ degree of freedom $=4.3, \mathrm{RMSEA}=0.09, \mathrm{GFI}=0.875, \mathrm{CFI}=0.800, \mathrm{AGFI}$ $=0.826)$. While the adjusted goodness-of-fit index (CFI) value is 0.80 , a little smaller than the criteria (0.85), suggesting a slight weakness of the model fit, the value above 0.731 cannot be rejected (Chou, Bentler 1990). Furthermore, the $\mathrm{R}^{2}$ values for all endogenous latent variables $\left(\mathrm{R}_{\text {satisfaction }}^{2}=0.61, \mathrm{R}_{\text {loyalty }}^{2}=0.57\right)$ exceed $10 \%$, implying a satisfactory and substantive model (Falk, Miller 1992). Accordingly, the final SEM in Figure 3 is supported by the results of the GOF indices. Six standardized path coefficients between latent variables were significant at $\mathrm{p}<0.05$, indicating that $\mathrm{H} 1, \mathrm{H} 4, \mathrm{H} 7, \mathrm{H} 8$, and $\mathrm{H} 11$ were supported yet $\mathrm{H} 5$ was opposite to the original hypothesis. The other five hypotheses were not significant and hence were not supported.

The indirect effects of the five managerial drivers on construction labour loyalty were tested for significance by adopting the Bootstrap estimation procedure in AMOS (a bootstrap sample of 2000 was specified). Table 4 shows the indirect effects and their associated 95\% confidence intervals. For bias-corrected and accelerated confidence interval, if zero is not between the lower and 
Table 3. Results of the measurement model

\begin{tabular}{|c|c|c|c|c|c|c|c|c|}
\hline $\begin{array}{c}\text { Latent } \\
\text { variable }\end{array}$ & Item & $\begin{array}{l}\text { Standard } \\
\text { Loading }\end{array}$ & S.E. & C.R. & $p$ & Cronbach's alpha & $\mathrm{CR}$ & AVE \\
\hline \multirow[t]{3}{*}{$\mathrm{ME}$} & ME2 & 0.644 & - & - & $\ldots$ & \multirow[t]{3}{*}{0.7} & \multirow[t]{3}{*}{0.7} & \multirow[t]{3}{*}{0.5} \\
\hline & ME3 & 0.770 & 0.138 & 9.881 & $* * *$ & & & \\
\hline & ME4 & 0.564 & 0.100 & 8.671 & $* * *$ & & & \\
\hline \multirow[t]{3}{*}{ OLE } & OLE1 & 0.726 & - & - & - & \multirow[t]{3}{*}{0.7} & \multirow[t]{3}{*}{0.7} & \multirow[t]{3}{*}{0.5} \\
\hline & OLE2 & 0.550 & 0.062 & 9.840 & $* * *$ & & & \\
\hline & OLE3 & 0.733 & 0.088 & 12.785 & $* * *$ & & & \\
\hline \multirow[t]{3}{*}{ Rw } & Rw1 & 0.578 & 0.090 & 8.890 & $* * *$ & \multirow[t]{3}{*}{0.7} & \multirow[t]{3}{*}{0.6} & \multirow[t]{3}{*}{0.4} \\
\hline & Rw2 & 0.594 & - & - & $\ldots$ & & & \\
\hline & Rw3 & 0.640 & 0.103 & 9.544 & $* * *$ & & & \\
\hline \multirow[t]{3}{*}{ JS } & JS1 & 0.551 & - & - & _ & \multirow[t]{3}{*}{0.7} & \multirow[t]{3}{*}{0.7} & \multirow[t]{3}{*}{0.4} \\
\hline & JS2 & 0.708 & 0.148 & 9.287 & $* * *$ & & & \\
\hline & JS3 & 0.669 & 0.182 & 9.035 & $* * *$ & & & \\
\hline \multirow[t]{2}{*}{$\mathrm{Cm}$} & $\mathrm{Cm} 2$ & 0.936 & - & - & - & \multirow[t]{2}{*}{0.8} & \multirow[t]{2}{*}{0.8} & \multirow[t]{2}{*}{0.7} \\
\hline & $\mathrm{Cm} 3$ & 0.686 & 0.060 & 11.450 & $* * *$ & & & \\
\hline \multirow[t]{2}{*}{$\mathrm{Sf}$} & Sf1 & 0.713 & 0.107 & 11.625 & $* * *$ & \multirow[t]{2}{*}{0.7} & \multirow[t]{2}{*}{0.7} & \multirow[t]{2}{*}{0.5} \\
\hline & Sf2 & 0.714 & - & - & $\ldots$ & & & \\
\hline \multirow[t]{2}{*}{ Ly } & Ly1 & 0.786 & - & - & - & \multirow[t]{2}{*}{0.6} & \multirow[t]{2}{*}{0.7} & \multirow[t]{2}{*}{0.5} \\
\hline & Ly2 & 0.602 & 0.082 & 8.466 & $* * *$ & & & \\
\hline
\end{tabular}

Note: "***" indicates $\mathrm{p}<0.001$, “**” indicates $\mathrm{p}<0.05$. Six paths with " " represent the baseline of parameter estimation.

upper bound, then it can be claimed that an indirect effect exists. Otherwise, an indirect effect does not exist (Mackinnon et al. 2007). Accordingly, it was found that the indirect effect estimates for living environment and rewards were significant $(\mathrm{p}<0.05)$ respectively, whereas the standardized direct estimates were found to be not significant, indicating full mediation of satisfaction in affecting labour loyalty. Moreover, external environment, job system and communication showed significant standardized estimates of direct effects, providing evidence of non-mediation.

\section{Findings and discussions}

According to the research results and practical issues, two types of influence paths for enhancing construction labour loyalty in international projects were identified. Path 1 includes the direct effects, macro environment, job system or communication - loyalty, whereas path 2 includes the indirect effects, living environment or rewards - satisfaction - loyalty. Accordingly, two types of measures to enhance labour loyalty are recommended.

\subsection{Long-term strategic orientation toward improving labour loyalty}

A disciplined and fair job system and a favourable macroenvironment, namely the combination of internal and external environments, play decisive roles in forming construction labour loyalty to an organization. Specifically, an effective job system and an adaptation to external en- vironment were regarded as active tools for establishing labour's trust in management and forming a sense of belonging, respectively (Sun 2003). However, establishing trust and forming a sense of belonging will inevitably be time consuming; hence, Path 1 represents a relatively long-term strategic orientation toward improving labour loyalty (Lin et al. 2006).

A positive relationship between job system and construction labour loyalty is confirmed. The result indicates that the level of international construction labour loyalty will improve as job system becomes more effective. The job system reported in this study is constructed by the workload assignment system (standardized coefficient $=$ $0.73, \mathrm{p}<0.001$ ), work safety system (standardized coefficient $=0.65, \mathrm{p}<0.001$ ) and incentive system (standardized coefficient $=0.56, \mathrm{p}<0.001$ ). Obviously, reasonable workload assignment and work safety system are the two most important variables. The productivity of workers in international projects is relatively lower than that in the home country due to a high degree of uncertainty (Ling et al. 2012), but the workloads are not effortless, so an effective and fair workload assignment fosters labour identification with the management. Additionally, construction labour is much concerned about the potential safety issues at construction sites (Abrey, Smallwood 2014), so safe work system improves labourers' trust in the management. To sum up, an effective job system helps to establish sound foundations for labour's identification with and trust in the management, thereby actively enhancing construction labour loyalty. 


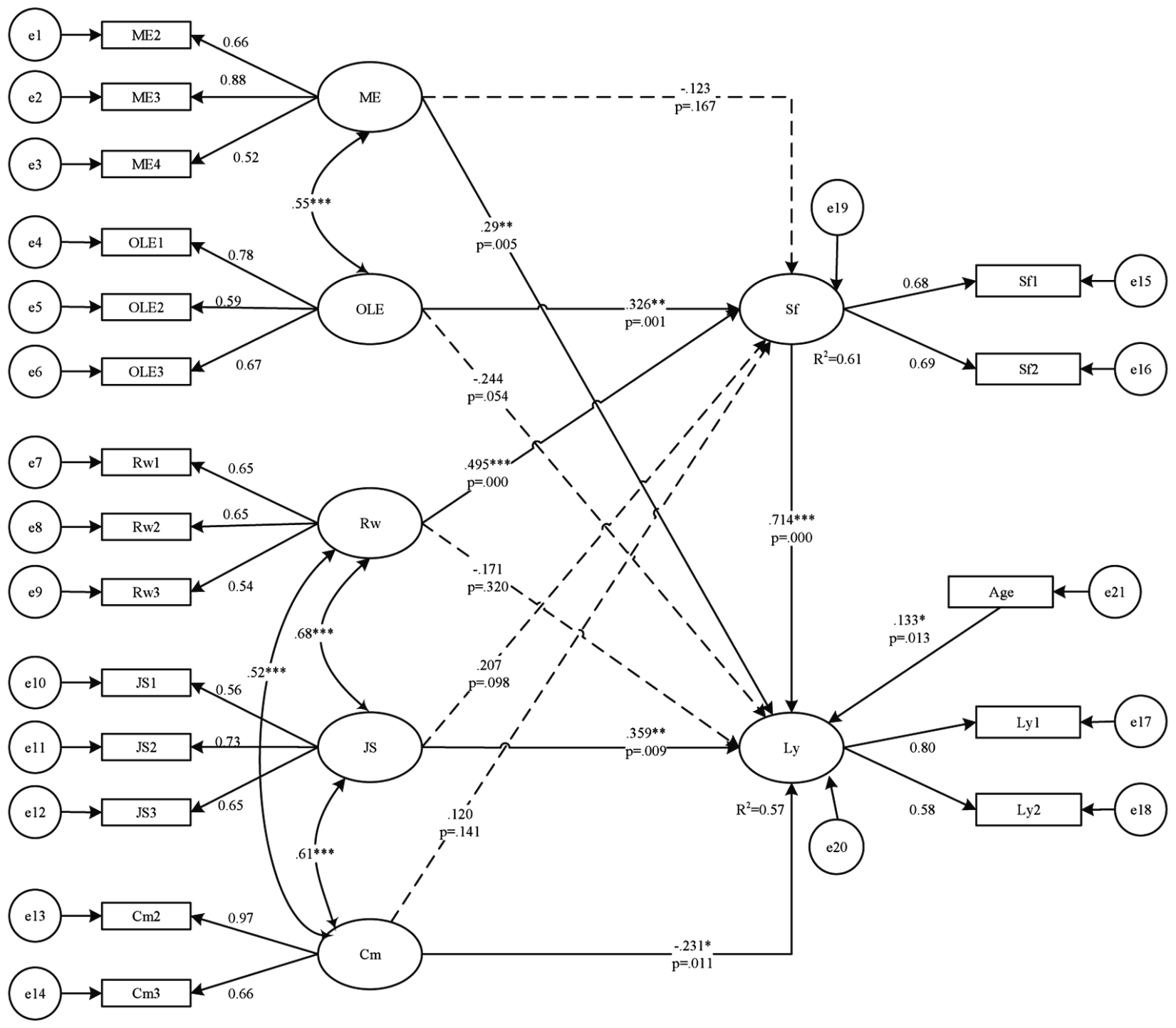

Notes: Solid line indicates a significant path (hypothesis supported); dashed line indicates an insignificant path (hypothesis not supported) ${ }^{* * *} p<.001 ; * * p<.01 ;{ }^{*} p<.05$

Fig. 3. Derived structural equation model

Table 4. Indirect effects and $95 \%$ confidence intervals for the final model

\begin{tabular}{lcccccc}
\hline \multirow{2}{*}{ Indirect Effect Paths } & \multirow{2}{*}{$\begin{array}{c}\text { Estimated } \\
\text { effect }\end{array}$} & \multicolumn{3}{c}{ 95\% CI } & P & Interpretation \\
& & Lower bounds & Upper bounds & & \\
\hline Macro environment - Satisfaction - Loyalty & -0.088 & -0.343 & 0.047 & 0.201 & Not Supported \\
\hline Living environment - Satisfaction - Loyalty & 0.232 & 0.061 & 0.584 & 0.001 & Supported \\
\hline Rewards - Satisfaction - Loyalty & 0.354 & 0.114 & 0.877 & 0.002 & Supported \\
\hline Job system - Satisfaction - Loyalty & 0.147 & -0.076 & 0.438 & 0.153 & Not Supported \\
\hline Communication - Satisfaction - Loyalty & 0.085 & -0.039 & 0.255 & 0.148 & Not Supported \\
\hline
\end{tabular}

A positive relationship between the macro-environment of project host country and construction labour loyalty is confirmed. Butcher et al. (2001) considered that one's feeling of anxiety or relaxation arising from the external social interaction has influence on his/her loyalty. In the international construction sites, unfavourable macro environment of project host country makes the work- ers feel difficult in adjusting to the strange project host countries and easily generates a feeling of anxiety. Backward medical facilities, the chaos of the security environment and the depression of the economic situation will make labour harbour more worries and cannot be fully devoted into their job, which shakes the labour's original intention that participating in international projects is for 
making money. These influence on labour from the external macro-environment will lead to the intention of labour turnover and decrease the endurance of dissatisfaction. Therefore, the international contractor, before undertaking some international projects, should pay attention to the project country's macro-environment, especially for the economy, social security and medical service.

A significant yet negative relationship is found between communication and construction labour loyalty. This finding is not line with Smith and Rupp (2002), who held that communication with knowledge workers is essential for developing loyalty because communication is for knowledge transferring, interactive learning, collaborative learning and sharing of learning. Once the phenomenon of missed communication, withheld communication or incorrect communication is perceived, the knowledge worker is already beginning disengagement. However, construction labourers are markedly different from knowledge worker. The simplicity and repetition of ordinary construction labourer's tasks determine that their frequency of communication at work is much less the knowledge workers'. Also, an expert interview on labour communication was conducted, and it was concluded that the communication from the ordinary workers is mainly focused on the personal interests, like salary and task assignments. Such communication will gradually have an impact on the comparison of job salary or tasks assignments among the labourers, leading to a potential sense of inequity on salary or task assignment. Therefore, in the long run, the communication of personal interests beyond the scope of work may have negative effect on labour loyalty to the organization. Accordingly, high frequency of communication is not recommended among the ordinary workers in the international projects in a long term.

\subsection{Short-term tactical goals for labour loyalty enhancement}

According to Dainty et al. (2004), financial compensation is still a significant and basic resource for retaining employees in the construction industry. Path 2 is a passive way to improve construction labour loyalty; if living demands or rewards are not satisfied, construction labour will most likely leave the project organization (Sun 2003). Therefore, Path 2 provides short-term tactical goals for labour loyalty enhancement.

The significance of living environment - satisfaction - loyalty path demonstrates that living environment affects construction labour loyalty through the mediation of satisfaction. This finding is in line with Turkyilmaz et al. (2011), who found that the physical working environment positively influences employee satisfaction and that employee satisfaction in turn has positive effects on employee loyalty. Likewise, evidence supporting the significant mediating effects of satisfaction between rewards and labour loyalty indicates that rewards affect construction labour loyalty in indirect ways. This finding echoes in general the important role of rewards in the attainment of employee satisfaction, and job satisfaction has been found to be the most important tool for employee retention (Jun et al. 2006). The full mediation effects of job satisfaction in the relationships between the two managerial drivers and loyalty indicate that living environment and rewards offer hardly direct enhancement of labour loyalty. Rather, they promote labour satisfaction and then labour satisfaction in turn improves labour loyalty.

In the measurement models, organizational living environment is constructed by food (standardized coefficient $=0.78$ ), accommodations and housing facilities (standardized coefficient $=0.59, \mathrm{p}<0.001$ ), and leisure time (standardized coefficient $=0.67, \mathrm{p}<0.001$ ). Obviously, food and leisure time are the two most prominent variables. Accordingly, it is suggested that in addition to the food prepared for construction labour, some collective entertainment activities and supportive facilities for rest and relaxation should be provided on construction sites to enrich their lives. Furthermore, rewards are constructed by salary level (standardized coefficient $=$ 0.65 ), wage settlement (standardized coefficient $=0.65$, $\mathrm{p}<0.001$ ), and benefit package (standardized coefficient $=0.54, p<0.001)$. Since construction labourers are more concerned with salary, contractors should create a clear wage difference between international and home country projects and give wages to labourers on time.

\section{Conclusions}

The research reported in this paper quantitatively examined the effects of five managerial drivers on labour loyalty in international construction projects and demonstrated the significance of satisfaction as a mediating variable in the relationship between the managerial drivers and construction labour loyalty. Two types of influence paths (direct effects and indirect effects) for improving construction labour loyalty were identified. It is worth noting that the direct effect paths serve as a long-term strategic orientation for improving labour loyalty because it helps construction labourers far from their home country establish trust in contractors and produce a sense of belonging in the organization. The indirect effect paths are a tactic for short-term goals of labour loyalty enhancement because satisfied material needs are expedient measures.

The findings of this study contribute to the body of knowledge by addressing the role of the antecedents to labour loyalty in international construction projects, and they are also useful for labour management practice because they lead to suggestions that contractors could adopt to enhance construction labour loyalty in order to improve productivity. However, limited by time and energy, there might be other factors (e.g., types of project, the general contractor of the project) influencing labour loyalty. In the future research, these factors will be integrated to investigate additional antecedents of construction labour loyalty, with the purpose of generating a more precise understanding of factors influencing labour loyalty. 


\section{Acknowledgements}

The authors would also like to thank the General Manager, Mr. Jieqin Li of Overseas Business Department, China Construction Co., Ltd for his supports in the research process. In addition, the authors are indebted to the two managers, Ms. Yongchun Pan and Mr. Chun'an Li from the Department of Labour Management for providing an introduction to expert resources.

\section{Funding}

This work was supported by the two National Science Foundations of China (No. 51378297, No. 51778335).

\section{Disclosure statement}

All the authors have no conflict of interest.

\section{References}

Abrey, M.; Smallwood, J. J. 2014. The effects of unsatisfactory working conditions on productivity in the construction industry, Procedia Engineering 85: 3-9. https://doi.org/10.1016/j.proeng.2014.10.522

Allen, N. J.; Grisaffe, D. B. 2001. Employee commitment to the organization and customer reactions: mapping the linkages, Human Resource Management Review 11: 209-236. https://doi.org/10.1016/S1053-4822(00)00049-8

Anderson, J. C.; Gerbing, D. W. 1988. Structural equation modelling in practice: A review and recommended two-step approach, Psychological Bulletin 103: 411-423. https://doi.org/10.1037/0033-2909.103.3.411

Anne, M.; Grønholdt, L. 2007. Using employee satisfaction measurement to improve people management: An adaptation of Kano's quality types, Total Quality Management 12: 949-957. https://doi.org/10.1080/09544120100000020

Atiyyah, H. S. 1995. Adjustment of Asian workers to working and living conditions in Arab Gulf countries, Cross Cultural Management: An International Journal 2: 46-50.

Austin, J.; Droussiotis, A. 2007. Job satisfaction of managers in Cyprus, EuroMed Journal of Business 2: 208-222. https://doi.org/10.1108/14502190710826068

Becker, T. E.; Randall, D. M.; Riegel, C. D. 1995. The multidimensional view of commitment and the theory of reasoned action: A comparative evaluation, Journal of Management 21: 617-638. https://doi.org/10.1177/014920639502100402

Boltanski, L.; Chiapello, E. 1999. Le Nouvel Esprit du Capitalisme. Paris: Gallimard.

Butcher, K.; Sparks, B.; O'Callaghan, F. 2001. Evaluative and relational influences on service loyalty, International Journal of Service Industry Management 12: 310-327. https://doi.org/10.1108/09564230110405253

Carré, F. J. 2015. Working conditions, in J. D. Wright (Ed.). International encyclopedia of the social \& behavioral sciences. $2^{\text {nd }}$ ed. Elsevier, 698-702.

Chen, C. F. 2006. Job satisfaction, organizational commitment, and flight attendants' turnover intentions: A note, Journal of Air Transport Management 12: 274-276. https://doi.org/10.1016/j.jairtraman.2006.05.001

Chi, S.; Han, S.; Kim, D. Y. 2013. Relationship between unsafe working conditions and workers' behaviour and impact of working conditions on injury severity in U.S. construction industry, Journal of Construction Engineering and Management 139: 826-838.

https://doi.org/10.1061/(ASCE)CO.1943-7862.0000657
Chih, Y.-Y.; Kiazad, K.; Zhou, L.; Capezio, A.; Li, M.; Restubog, S. L. D. 2016. Investigating employee turnover in the construction industry: A psychological contract perspective, Journal of Construction Engineering and Management 142, 04016006.

https://doi.org/10.1061/(ASCE)CO.1943-7862.0001101

Chou, C. P.; Bentler, P. M. 1990. Model modification in covariance structure modelling: A comparison among likelihood ratio, Lagrange multiplier, and Wald tests, Multivariate Behavioural Research 25: 115. https://doi.org/10.1207/s15327906mbr2501_13

Clark, L. A.; Watson, D. 1995. Constructing validity: basic issues in objective scale development, Psychological Assessment 7: 309-319. https://doi.org/10.1037/1040-3590.7.3.309

Dainty, A. R. J.; Raiden, A. B.; Neale, R. H. 2004. Psychological contract expectations of construction project managers, Engineering Construction \& Architectural Management 11: 33-44. https://doi.org/10.1108/09699980410512647

Doloi, H.; Sawhney, A.; Iyer, K. C.; Rentala, S. 2012. Analysing factors affecting delays in Indian construction projects, International Journal of Project Management 30: 479-489. https://doi.org/10.1016/j.ijproman.2011.10.004

Duboff, R.; Heaton, C., 2013. Employee loyalty: a key link to value growth, Strategy \& Leadership 27: 8-13. https://doi.org/10.1108/eb054624

Enshassi, A.; Mohamed, S.; Mustafa, Z. A.; Mayer, P. E. 2007. Factors affecting labour productivity in building projects in the Gaza strip, Journal of Civil Engineering and Management 13(4): 245-254.

Eskildsen, J. K.; Nussler, M. L. 2000. The managerial drivers of employee satisfaction and loyalty, Total Quality Management 11: 581-588. https://doi.org/10.1080/09544120050007913

Falk, R. F.; Miller, N. B. 1992. A primer for soft modelling. University of Akron Press.

Fini, A. A. F.; Akbarnezhad, A.; Rashidi, T. H.; Waller, S. T. 2016. Job assignment based on brain demands and human resource strategies, Journal of Construction Engineering and Management, 04016123.

Fornell, C.; Larcker, D. F. 1981. Evaluating structural equation models with unobservable variables and measurement error, Journal of Marketing Research 18: 39-50. https://doi.org/10.2307/3151312

Gronroos, C. 1981. Internal marketing - an integral part of marketing theory, in J. H. Donnelly and W. E. George (Eds). Marketing of services. American Marketing Association Proceedings Series.

Guillon, O.; Cezanne, C. 2014. Employee loyalty and organizational performance: a critical survey, Journal of Organizational Change Management 27: 839-850. https://doi.org/10.1108/JOCM-02-2014-0025

Hair, J. F.; Hult, G. T. M.; Ringle, C.; Sarstedt, M. 2014. A primer on partial least squares structural equation modelling (PLS-SEM) | NOVA. Sage.

Han, S. H.; Sang, H. P.; Jin, E. J.; Kim, H.; Seong, Y. K. 2008. Critical issues and possible solutions for motivating foreign construction workers, Journal of Management in Engineering 24: 217-226. https://doi.org/10.1061/ (ASCE)0742-597X(2008)24:4(217)

He, Z. 1995. Risk management for overseas construction projects, International Journal of Project Management 13: 231-237. https://doi.org/10.1016/0263-7863(95)00015-I

Helgesen, Ø.; Håvold, J. I.; Nesset, E. 2010. Impacts of store and chain images on the "quality-satisfaction-loyalty process" in petrol retailing, Journal of Retailing \& Consumer Services 17: 109-118. https://doi.org/10.1016/j.jretconser.2009.11.001 
Hinze, J.; Ugwu, M.; Hubbard, L. 1985. Absenteeism in construction industry, Journal of Management in Engineering 1: $188-200$. https://doi.org/10.1061/(ASCE)9742-597X(1985)1:4(188)

Ineson, E. M.; Berechet, G. 2011. Employee loyalty in hotels: Romanian experiences, Journal of Human Resources in Hospitality \& Tourism 10: 129-149. https://doi.org/10.1080/15332845.2011.536694

Jones, S. M.; Ross, A.; Sertyesilisik, B. 2010. Testing the unfolding model of voluntary turnover on construction professionals, Construction Management and Economics 28: 271-285. https://doi.org/10.1080/01446191003587737

Jun, M.; Cai, S.; Shin, H. 2006. TQM practice in maquiladora: Antecedents of employee satisfaction and loyalty, Journal of Operations Management 24: 791-812. https://doi.org/10.1016/j.jom.2005.09.006

Kazaz, A.; Manisali, E.; Ulubeyli, S. 2013. Effect of basic motivational factors on construction workforce productivity in Turkey, Journal of Civil Engineering and Management 14(2): 95-106.

http://dx.doi.org/10.3846/1392-3730.2008.14.4

Kazemzadeh, R. B.; Bashiri, M. 2005. Determination of critical factors on employee satisfaction - a case study on a financial institute, in Proceedings of the Engineering Management Conference, 2005, IEEE International, 11-18.

Kline, R. B. 2005. Principles and practice of structural equation modelling. Guilford Press.

Kumar, D. N. S.; Shekhar, N. 2013. Perspectives envisaging employee loyalty, Journal of Management Research 12(2): 100.

Lin, B. W.; Hung, S. C.; Li, P. C. 2006. Mergers and acquisitions as a human resource strategy: Evidence from US banking firms, International Journal of Manpower 27: 126-142. https://doi.org/10.1108/01437720610666173

Ling, F. Y. Y.; Dulaimi, M. F.; Chua, M. H. 2012. Strategies for managing migrant construction workers from China, India, and the Philippines, Journal of Professional Issues in Engineering Education \& Practice 139: 19-26.

Linz, S. J.; Chu, Y. W. L. 2014. Work ethic in formerly socialist economies, Journal of Economic Psychology 39: 185-203. https://doi.org/10.1016/j.joep.2013.07.010

Linz, S.; Good, L. K.; Busch, M. 2015. Promoting worker loyalty: an empirical analysis, International Journal of Manpower 36: 399-404. https://doi.org/10.1108/IJM-06-2013-0129

Liu, J.; Zhao, X.; Yan, P. 2016. Risk paths in international construction projects: Case study from Chinese contractors, Journal of Construction Engineering and Management 142, 05016002. https://doi.org/10.1061/(ASCE)CO.1943-7862.0001116

Mackinnon, D. P.; Fritz, M. S.; Williams, J.; Lockwood, C. M. 2007. Distribution of the product confidence limits for the indirect effect: program PRODCLIN, Behaviour Research Methods 39: 384-389.

https://doi.org/10.3758/BF03193007

Marin-García, J. A.; Bonavia, T.; Losilla, J. M. 2011. Exploring working conditions as determinants of job satisfaction: an empirical test among Catalonia service workers, Service Industries Journal 31: 2051-2066.

https://doi.org/10.1080/02642069.2011.559226

Martensen, A.; Grønholdt, L. 2006. Internal marketing: a study of employee loyalty, its determinants and consequences, Innovative Marketing 2(4).

Maruish, M. E. 2004. The use of psychological testing for treatment planning and outcomes assessment. Vol. 1. Lawrence Erlbaum Associates.

Matzler, K.; Renzl, B. 2007. The relationship between interpersonal trust, employee satisfaction, and employee loy- alty, Total Quality Management \& Business Excellence 17: 1261-1271. https://doi.org/10.1080/14783360600753653

Mcclenahen, J. S. 2003. The next crisis: too few workers. Industry Week.

Mcmullan, R.; Gilmore, A. 2003. The conceptual development of customer loyalty measurement: A proposed scale, Journal of Targeting, Measurement and Analysis for Marketing 11: 230-243. https://doi.org/10.1057/palgrave.jt.5740080

Narteh, B.; Odoom, R. 2015. Does internal marketing influence employee loyalty? Evidence from the Ghanaian banking industry, Services Marketing Quarterly 36: 112-135. https://doi.org/10.1080/15332969.2015.1014237

Othman, A. A. E. 2014. An international index for customer satisfaction in the construction industry, International Journal of Construction Management 4: 17-32. https://doi.org/10.6106/JCEPM.2014.4.4.017

Ozorhon, B.; Arditi, D.; Dikmen, I.; Birgonul, M. T. 2007. Effect of host country and project conditions in international construction joint ventures, International Journal of Project Management 25: 799-806. https://doi.org/10.1016/j.ijproman.2007.05.003

Pan, Y.; Zinkhan, G. M. 2006. Determinants of retail patronage: A meta-analytical perspective, Journal of Retailing 82: 229-243. https://doi.org/10.1016/j.jretai.2005.11.008

Piore, M. J. 1990. Labour standards and business strategies, in S. Herzenberg and J. F. Perez-Lopez, J. F. (Eds). Labour standards and development in the global economy. MIT Economics.

Podsakoff, P. M.; Organ, D. W. 1986. Self-reports in organizational research: Problems and prospects, Journal of Management: Official Journal of the Southern Management Association 12: 531-544. https://doi.org/10.1177/014920638601200408

Ringle, C. M.; Sarstedt, M.; Straub, D. W. 2012. Editor's comments: a critical look at the use of PLS-SEM in MIS quarterly, Mis Quarterly 36: 3-14.

Ryan, M. J.; Buzas, T.; Venkatram, R. 1995. Making CSM a power tool. Marketing Research. American Marketing Association.

Shan, Y.; Goodrum, P. M. 2010. Worker satisfaction and worklife related characteristics in the U.S. construction industry, in Construction Research Congress 2010, 1064-1073.

Smith, P. C. 1969. The measurement of satisfaction in work and retirement; a strategy for the study of attitudes [by] Patricia Cain Smith, Lorne M. Kendall [and] Charles L. Hulin. Rand McNally, Chicago, Ill.

Smith, A. D.; Rupp, W. T. 2002. Communication and loyalty among knowledge workers: a resource of the firm theory view, Journal of Knowledge Management 6: 250-261. https://doi.org/10.1108/13673270210434359

Steele, A.; Sodhi, D. 2006. Race, ethnic minorities and construction industry, in A. W. Gale and M. J. Davidson (Eds). Managing diversity and equality in construction: Initiatives and practice. London: Taylor and Francis, 195-208.

Sun, J. 2003. How to foster the staff loyalty. Enterprise Management Publication House.

Tsigilis, N.; Zachopoulou, E.; Grammatikopoulos, V. 2006. Job satisfaction and burnout among Greek early educators: a comparison between public and private sector employees, Educational Research and Reviews 1: 256-261.

Turkyilmaz, A.; Akman, G.; Ozkan, C.; Pastuszak, Z. 2011. Empirical study of public sector employee loyalty and satisfaction, Industrial Management and Data Systems 111: 675-696. https://doi.org/10.1108/02635571111137250

Xiong, B. Skitmore, M.; Xia, B. 2015. A critical review of structural equation modelling applications in construction research, Automation in Construction 49: 59-70. https://doi.org/10.1016/j.autcon.2014.09.006 
Wang, L. 2006. International project risk management research, Business.

Ye, K.; Zhu, W.; Shan, Y.; Li, S. 2015. Effects of market competition on the sustainability performance of the construction industry: China case, Journal of Construction Engineering and Management 141, 04015025. https://doi.org/10.1061/(ASCE)CO.1943-7862.0000999
Zeithaml, V. A.; Parasuraman, A. 1996. The behavioural consequences of service quality, Journal of Marketing 60: 31-46. https://doi.org/10.2307/1251929

Zhou, C. 2010. Implementation of the Labour Contract Law in the context of the global financial crisis: the function and limits of judicial activism in labour dispute resolution, 5: 15-23 (in Chinese).

Weina ZHU. PhD Candidate of Dept. of Construction Management, School of Civil Engineering, Tsinghua Univ., Beijing 100084, China. She has published 3 journal and conference papers. Research interests: sustainability in construction, and occupational health in construction.

Ruochen ZENG. PhD Candidate of M.E Rinker, Sr. School of Construction Management at University of Florida. He has published 1 journal paper. Research interests: sustainable construction and environmental impacts of construction.

Xiaodong LI. PhD Assoc. Prof. of Dept of Construction Management, School of Civil Engineering, Tsinghua Univ., Beijing 100084, China. He received his Doctoral degree of Management Science and Engineering at Harbin Institute of Technology. He has published more than 70 journal and conference papers. Research interests: construction sustainability management, occupational health in construction.

Yi ZHU. Master in Management Science and Engineering of Dept. of Construction Management, School of Civil Engineering, Tsinghua Univ., Beijing 100084, China. He is currently employed in Huarong Rongde Asset Management CO., LTD, Beijing, China. He has published 2 journal papers. Research interests: human resource management.

Zhihui ZHANG. Prof. of Dept of Construction Management, School of Civil Engineering, Tsinghua Univ., Beijing 100084, China. He received his Doctoral degree of Construction Management and Economics at Harbin Institute of Technology. He has published more than 80 journal and conference papers. Research interests: construction economics and construction project management, environmental impact assessment in construction. 